\title{
Differences in immunochemical characteristics of cryoglobulins in rheumatoid arthritis and systemic lupus erythematosus and their complement binding properties
}

\author{
C. C. ERHARDT, PAT MUMFORD, AND R. N. MAINI
}

From the Kennedy Institute of Rheumatology, 6 Bute Gardens, London W6 7DW, and Charing Cross Hospital, Fulham Palace Road, London W6 8RF

SUMMARY Cryoglobulins isolated from sera of patients with rheumatoid arthritis (RA) and systemic lupus erythematosus (SLE) were analysed for their immunoglobulin, antibody, and complement components. In both disease categories the cryoglobulins contained predominantly IgG with lesser amounts of $\operatorname{IgM}$ and $\operatorname{IgA}$, but relative to serum more $\operatorname{IgM}$ was concentrated in the cryoglobulins. IgM rheumatoid factor was found in $65 \%$ of RA cryoglobulins but in only $17 \%$ of SLE cryoglobulins $(p<0.02)$, whereas SLE cryoglobulins contained more DNA binding activity than RA cryoglobulins $(p<0 \cdot 01)$. C1q binding activity was detectable in the majority of SLE and RA sera and SLE cryoglobulins. Paradoxically only two out of 34 RA cryoglobulins bound C1q, although rheumatoid factor activity was present in both cryoglobulins and sera. When isolated from serum the rheumatoid factor fraction strongly bound C1q. Both RA and SLE cryoglobulins contained similar small amounts of $\mathrm{C} 3$ and C4. Differences in antibody composition and complement binding activity of cryoglobulins from RA and SLE sera may reflect properties of immune complexes which affect their tissue localisation and pathogenicity.

Sera from patients with RA and SLE contain circulating immune complexes detectable by a number of assays. ${ }^{1}$ Circulating immune complexes detected by cryoglobulinaemia in patients with RA are associated with certain extra-articular disease features considered to have a vascular or granulomatous basis. ${ }^{23}$ In patients with SLE cryoglobulinaemia correlates with the presence of renal disease. ${ }^{45}$ The pathogenicity of immune complexes is determined by their ability to localise in target tissues and activate complement, which is in turn related to the size and shape of the immune complexes and their antigen and antibody composition. ${ }^{67}$ This paper compares the immunoglobulin, rheumatoid factor, DNA antibody, and C3 and $\mathrm{C} 4$ composition of cryoglobulins prepared from sera of patients with RA and SLE. It also reports on the ability of these cryoglobulins to bind C1q. Sera from patients with cryoglobulinaemic purpura, con-

Accepted for publication 13 December 1983.

Correspondence to Dr C. C. Erhardt, Kennedy Institute of Rheumatology, 6 Bute Gardens, London W6 7DW. taining high levels of serum cryoglobulins, were used as controls.

\section{Materials and methods}

Blood samples were collected from patients into prewarmed glass bottles and clotted at $37^{\circ} \mathrm{C}$. The serum was separated at $37^{\circ} \mathrm{C}$, and $10 \mathrm{ml}$ were placed in a plastic tube containing approximately $2 \mathrm{mg}$ of sodium azide for precipitation and quantitation of cryoglobulin as previously described. ${ }^{3}$ Another aliquot of serum was frozen and stored at $-20^{\circ} \mathrm{C}$ for measurement of circulating immune complexes.

IgM rheumatoid factor was measured by a tube latex agglutination test employing the RheumaWellcotest from Wellcome Diagnostics. Anti-DNA antibodies were quantitated by a Farr assay using the Amersham International kit. ${ }^{8}$ For measurement of cryoglobulin rheumatoid factor and DNA antibody titres the diluting buffer was prewarmed to $37^{\circ} \mathrm{C}$. Antibodies to extractable nuclear antigens were detected by counterimmunoelectrophoresis and double diffusion as previously described. ${ }^{9}$ 
The antiglobulin fraction from sera was partially purified by an affinity chromatography column. The immunoadsorbent was Cohn fraction II coupled to cyanogen bromide activated Sepharose 4B. The coupling buffer was $0.1 \mathrm{M}$ sodium bicarbonate, $\mathrm{pH}$ $8 \cdot 3$, and the eluting buffer $0 \cdot 1 \mathrm{M}$ glycine adjusted to $\mathrm{pH} 2 \cdot 8$ with hydrochloric acid, both buffers containing $0.5 \mathrm{M}$ sodium chloride. Unoccupied reactive sites were blocked by incubation of the immunoadsorbent in $1 \mathrm{M}$ ethanolamine overnight at $4^{\circ} \mathrm{C}$ and passage of normal human serum before the rheumatoid serum was applied. The eluted antiglobulin fraction was dialysed against phosphate buffered saline, and its protein, immunoglobulin, and rheumatoid factor content were measured in the same way as that of cryoglobulins.

Serum ${ }^{125} \mathrm{I} \mathrm{C} 1 \mathrm{q}$ binding activity (C1qBA) was measured by the method of Zubler et al. ${ }^{10}$ The assay was performed on the whole serum, the cryoglobulin, and the cryoglobulin supernatant in the same assay to avoid interassay variation. Measurement of C1qBA of cryoglobulins and column fractions was performed after standardisation of their protein content by mixing $50 \mu \mathrm{l}$ of the cryoglobulin solution with $50 \mu \mathrm{l}$ of $0.2 \mathrm{M}$ ethylenediamine tetra-acetic acid (EDTA) and $50 \mu \mathrm{l}$ of normal human serum which had been dialysed against $0 \cdot 2 \mathrm{M}$ EDTA. ${ }^{10}$

Complement levels in cryoglobulins were measured by rocket immunoelectrophoresis using a modification of a standard method. ${ }^{11} 0 \cdot 8 \%$ agarose was used in $0.2 \mathrm{M}$ barbitone buffer containing 0.01 $\mathrm{M}$ EDTA. Commercial anti-C3 and anti-C4 antisera (Behringwerke) were included in the gel and dilu- tions of Human Serum Standard (Behringwerke) used for calibration.

The serum cryoglobulins examined in this study had protein concentrations greater than $10 \mu \mathrm{g} / \mathrm{ml}$ of original serum, which was the highest cryoglobulin protein found in 26 normal sera. The sera were obtained from patients with RA who fulfilled diagnostic criteria for classical or definite disease ${ }^{12}$ and patients with SLE who also fulfilled diagnostic criteria. ${ }^{13}$ Four patients with cryoglobulinaemic purpura were included in the study. In addition to a purpuric rash one of these patients had Sjögren's syndrome, but systemic disease was absent in the other three patients. All four sera and cryoglobulins were negative for hepatitis B surface antigen and antibody.

Statistical analysis. The $\chi^{2}$ test with Yates's correction and Wilcoxon's sum of ranks test were used.

\section{Results}

\section{IMMUNOGLOBULIN COMPOSITION OF} CRYOGLOBULINS

Cryoglobulin IgG, IgA, and IgM was quantitated by single radical immunodiffusion at $37^{\circ} \mathrm{C}$. By this method the sum of IgG + IgA + IgM accounted for a mean of $73 \%$ (range $20-100 \%$ ) of cryoglobulin protein from 66 rheumatoid arthritis sera and a mean of $52 \%$ (range $20-100 \%$ ) of cryoglobulin protein from 13 SLE sera.

The concentrations of cryoprecipitable immunoglobulin are given in Table 1, which shows that the predominant immunoglobulin class which precipi-

Table 1 Characteristics of cryoglobulins in RA, SLE, and cryoglobulinaemic purpura

\begin{tabular}{|c|c|c|c|c|}
\hline & & $R A$ & $S L E$ & $\begin{array}{l}\text { Cryoglobulinaemic } \\
\text { purpura }\end{array}$ \\
\hline \multirow{2}{*}{ Percentage of patients with serum cryoglobulin $>10 \mu \mathrm{g} / \mathrm{ml}$} & & 38 & 67 & 100 \\
\hline & G & $11 \cdot 4$ & $8 \cdot 3$ & 248 \\
\hline \multirow[t]{2}{*}{ Cryo. Ig $(\mu \mathrm{g} / \mathrm{ml})^{*}$} & M & $6 \cdot 3$ & $6 \cdot 8$ & 163 \\
\hline & A & $0 \cdot 8$ & $1 \cdot 1$ & 61 \\
\hline \multirow{2}{*}{ Cryo. Ig $(\mu \mathrm{g} / \mathrm{ml})=10^{4}$} & G & 7 & 5 & \\
\hline & $\begin{array}{l}\mathbf{M} \\
\mathbf{A}\end{array}$ & $\begin{array}{l}32 \\
2\end{array}$ & $\begin{array}{l}49 \\
3\end{array}$ & ND \\
\hline \multirow{2}{*}{$\begin{array}{l}\text { Serum } \operatorname{Ig}(\mu \mathrm{g} / \mathrm{ml}) \\
\text { IgM rheumatoid factor }\end{array}$} & $\%$ positive & 65 & 17 & 75 \\
\hline & Median titre & $1: 40$ & 0 & $1: 2560$ \\
\hline \multirow[t]{2}{*}{ DNA binding } & $\%$ positive & 57 & 95 & 25 \\
\hline & Median (units/ml) & 40 & 96 & 0 \\
\hline \multicolumn{2}{|l|}{ ENA antibodies } & 0 & 0 & 0 \\
\hline \multirow[t]{2}{*}{ C3 } & $\%$ positive & 57 & 92 & 100 \\
\hline & Mean $(\mu \mathrm{g} / \mathrm{ml})$ & $0 \cdot 07$ & $0 \cdot 10$ & $3 \cdot 1$ \\
\hline \multirow[t]{2}{*}{$\mathrm{C} 4$} & $\%$ positive & 43 & 50 & 100 \\
\hline & Mean $(\mu \mathrm{g} / \mathrm{ml})$ & 0.09 & $0 \cdot 08$ & $0 \cdot 6$ \\
\hline Fall of serum $\mathrm{ClqBA}$ on cold incubation & Mean $\%$ & 0 & 12 & 52 \\
\hline Cryoglobulin C1qBA & Mean \% & 8 & 17 & 75 \\
\hline
\end{tabular}

Mean values. $\mathrm{ND}=$ not done. 
tated was IgG, with lesser amounts of IgM and IgA. The mean concentration of IgG found in SLE cryoglobulins was slightly lower than that found in RA cryoglobulins (not statistically significant), but the concentrations of $\operatorname{IgA}$ and IgM were similar. In comparison with serum levels relatively more IgM than IgG was concentrated in the cryoglobulins of both RA and SLE patients.

\section{RHEUMATOID FACTOR CONTENT OF \\ CRYOGLOBULINS}

Twenty-three RA serum cryoglobulins were tested for the presence of IgM rheumatoid factor by means of a standard latex agglutination test. Fifteen cryoglobulins $(65 \%)$ caused agglutination of latex particles in this test, the highest titre obtained being 1:640 and the median titre 1:40 (Table 1). In contrast $17 \%$ of 12 SLE cryoglobulins with similar protein concentrations gave positive latex tests $(\mathrm{p}<$ $0 \cdot 02, \chi^{2}$ test). Three out of four cryoglobulins from patients with cryoglobulinaemic purpura had positive latex tests, the titres being 1:2560 in two and $1: 1280$ in the third.

\section{ANTIBODIES TO DNA AND ENA}

A total of 31 cryoglobulins were tested for DNA binding activity, which was found in $95 \%$ of SLE cryoglobulins, $57 \%$ of those from RA sera and one out of four cryoglobulins from patients with cryoglobulinaemic purpura (Table 1). The DNA binding activity present in SLE cryoglobulins was higher than that seen in RA cryoglobulins with similar protein concentrations $(\mathrm{p}<0 \cdot 01$, Wilcoxon test $)$. The median enrichment of DNA binding activity in SLE cryoglobulins compared with matched serum was 89 -fold, a similar result to that obtained by Winfield et al. ${ }^{14}$

The DNA binding activity of 11 SLE sera, all from patients known to have cryoglobulinaemia, was measured after cold incubation and harvesting of the cryoglobulin and the result compared with the DNA binding activity of a rapidly frozen aliquot of the same serum. Five of the sera showed a fall in DNA binding activity greater than 10 units/ $\mathrm{ml}(110$, $50,25,20,18$ units $/ \mathrm{ml}$ ) suggesting the incorporation of DNA antibodies into the cryoglobulin.

Serum cryoglobulins from six RA patients, 10 SLE patients, and three patients with cryoglobulinaemic purpura were investigated for the presence of antibodies to extractable nuclear antigens (ENA). No cryoglobulin gave an immunoprecipitin line against rabbit thymus extract by either the counterimmunoelectrophoresis or double diffusion methods. The possibility exists that the absence of reaction might be caused by binding of antibodies to antigen already present in the cryoglobulin. There- fore a further aliquot of each cryoglobulin was treated with RNAse before testing and again no immunoprecipitin lines formed.

COMPLEMENT BINDING BY CRYOGLOBULINS AND THE ANTIGLOBULIN-CONTAINING SERUM FRACTION

In contrast to the high frequency of C1q-BA of RA sera only two isolated RA serum cryoglobulins out of 34 tested bound C1q (47\% and 15\%) (Fig. 1). The cryoglobulin protein of the first of these sera was $325 \mu \mathrm{g} / \mathrm{ml}$ (normal up to $10 \mu \mathrm{g} / \mathrm{ml}$ ), which was the highest recorded in this group of RA patients. The ClqBA of this serum measured after cold incubation and harvesting of the cryoglobulin was $14 \%$ lower than the $\mathrm{ClqBA}$ of the rapidly frozen aliquot. The other $33 \mathrm{RA}$ sera did not show a significant fall of $\mathrm{ClqBA}$ on cold incubation (Fig. $2)$; the ClqBA of $11 \mathrm{RA}$ sera rose on cold incubation, though significant rises $(16 \%$ and $11 \%)$ occurred in only two sera.

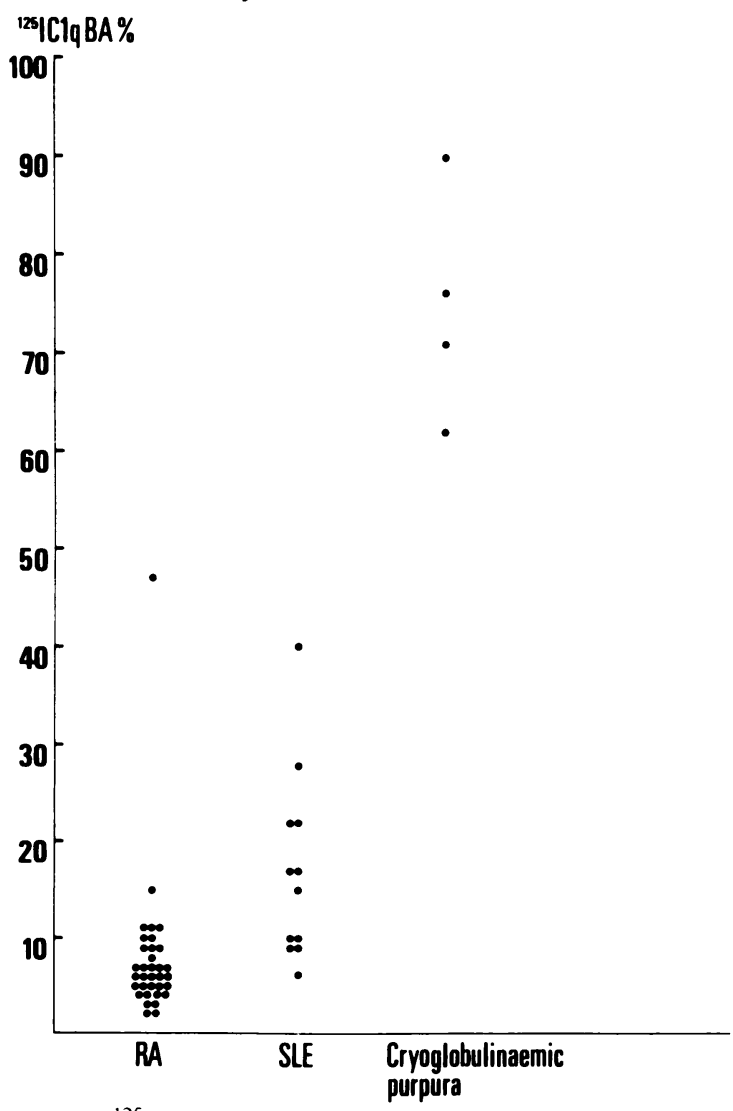

Fig. $1 \quad{ }^{125}$ I-Clq binding activity of serum cryoglobulins from patients with rheumatoid arthritis $(R A)$, systemic lupus erythematosus (SLE), and cryoglobulinaemic purpura. 


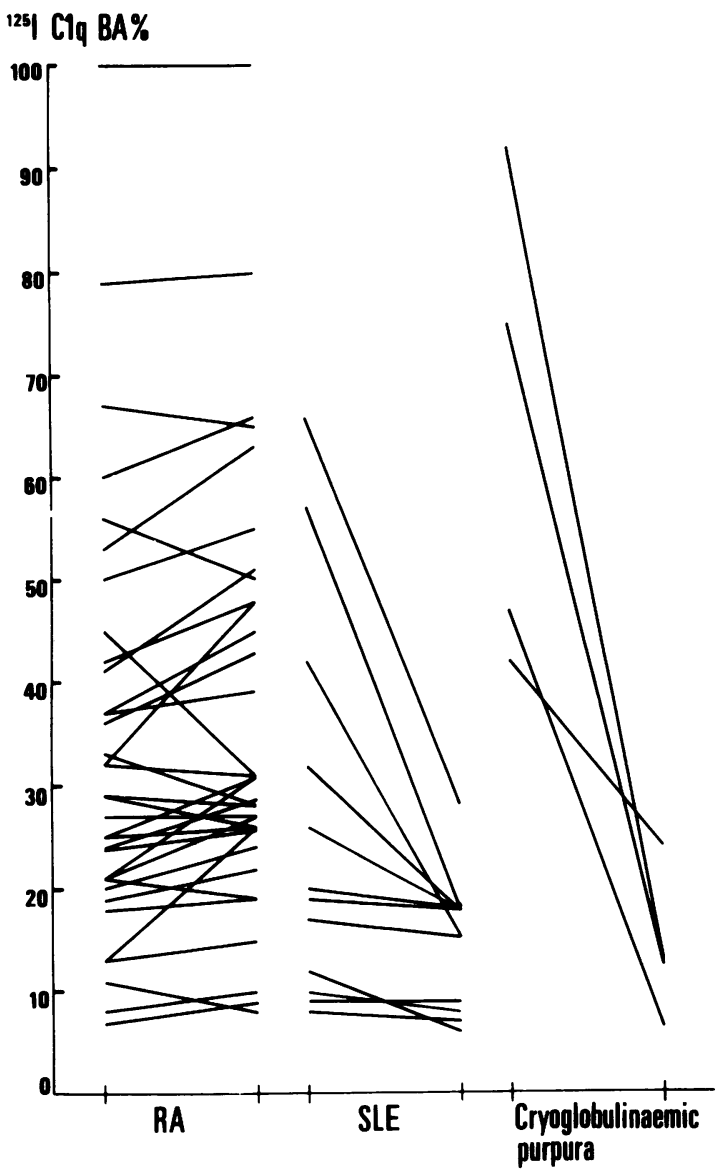

Fig 2 Serum ${ }^{125} \mathrm{I}-\mathrm{Cl} q$ binding activity before (left) and after (right) cold incubation and removal of the cryoglobulin.

The extent to which immune complexes containing rheumatoid factor accounted for the C1qBA of sera from four RA patients was investigated by an affinity column of aggregated human gammaglobulin bound to sepharose 4B. The results of these experiments, of which those in Table 2 are representative, showed that ClqBA was found mainly in the rheumatoid-factor-rich fraction. Affinity chromatography of a serum with a lower rheumatoid factor titre $(1: 160, \mathrm{C1qBA}: 24 \%)$ resulted in complete absorption of rheumatoid factor and $\mathrm{ClqBA}$ from the first drop-through fraction. The ratio of C1qBA to the sum of IgG and IgM was particularly high in the antiglobulin fraction, suggesting that much of the immunoglobulin in this fraction formed C1q binding immune complexes.

Seven out of 12 isolated cryoglobulins from SLE sera bound C1q (Fig. 1), and four of these sera
Table 2 Rheumatoid factor and ClqBA of serum fractions after affinity chromatography on Sepharose $4 B-H A G G$

\begin{tabular}{|c|c|c|c|}
\hline & $\begin{array}{l}\text { Whole } \\
\text { serum }\end{array}$ & Effluent & Acid eluate \\
\hline $\begin{array}{l}\text { Latex reciprocal } \\
\text { titre }\end{array}$ & $>40960$ & 1280 & 5120 \\
\hline Protein $\mathrm{g} / \mathrm{l}$ & $78 \cdot 8$ & $15 \cdot 3$ & 1.4 \\
\hline IgG g/l & $15 \cdot 8$ & $3 \cdot 6$ & $0 \cdot 18$ \\
\hline IgA g/l & $5 \cdot 2$ & 1.4 & $0 \cdot 07$ \\
\hline IgM g/I & $4 \cdot 3$ & $1 \cdot 6$ & $0 \cdot 66$ \\
\hline$\%^{125}$ I ClqBA & 98 & 22 & 65 \\
\hline$\%^{125} \mathrm{I}$ ClqBA & 4.9 & $4 \cdot 2$ & 77 \\
\hline
\end{tabular}

showed a fall of ClqBA in the supernatant serum after the cryoglobulin was harvested (Fig. 2). All four isolated cryoglobulins from patients with cryoglobulinaemic purpura bound large amounts of C1q. and the $\mathrm{C1qBA}$ of the sera was markedly reduced by cold incubation.

Complement components $\mathrm{C} 3$ and $\mathrm{C} 4$ were quantitated by rocket immunoelectrophoresis in isolated cryoglobulins from 30 RA sera and 12 SLE sera with protein concentrations of greater than $10 \mu \mathrm{g} / \mathrm{ml}$. Only small amounts of $\mathrm{C} 3$ and $\mathrm{C} 4$ were detected by this method (Table 1). C3 and $\mathrm{C} 4$ each accounted for a maximum of $1.5 \%$ of the serum cryoprecipitable protein. All three isolated cryoglobulins tested from patients with cryoglobulinaemic purpura contained both $\mathrm{C} 3$ and $\mathrm{C} 4$. Although cryoglobulins from these patients contained $\mathrm{C} 3$ and $\mathrm{C} 4$ in greater amounts than cryoglobulins from RA and SLE patients, the highest proportion of cryoglobulin accounted for by these complement components was $0.7 \%$

\section{Discussion}

This paper compares the characteristics of cryoglobulins isolated from the sera of patients with RA and SLE in order to ascertain whether there are differences which may explain the different clinical features seen in these two conditions.

In this study, which included only patients with cryoglobulinaemia, the amounts and ratios of the immunoglobulin classes precipitated from sera of patients with RA and SLE was approximately the same. IgG was the predominant immunoglobulin class which is in agreement with previous findings in SLE cryoglobulins ${ }^{15}$ though in RA cryoglobulins Weisman and Zvaifler ${ }^{2}$ found approximately equal amounts of IgG and IgM. In both RA and SLE there was relative concentration of IgM in the 
cryoglobulins compared with the serum levels. It is likely that the IgM is concentrated in RA cryoglobulins by virtue of its antiglobulin activity, ${ }^{2}$ which we also confirmed. The absence of rheumatoid factor from the majority of SLE cryoglobulins precludes this explanation for the enrichment of IgM in these cryoglobulins.

The comparison performed in this paper showed the presence of DNA binding activity in cryoglobulins from patients with RA and SLE and from one patient with cryoglobulinaemic purpura. The incidence and level of DNA binding was higher in SLE cryoglobulins than in the other two conditions. Both DNA and DNA binding activity have previously been shown to be concentrated in cryoglobulins from patients with SLE. ${ }^{14} 16$ We also found a high incidence of DNA binding in RA cryoglobulins in contrast with the normal values obtained in sera. Our findings suggest that DNA antibodies are concentrated in RA cryoglobulins, though the possibility that DNA binds to non-immunoglobulin molecules such as $\mathrm{C}_{1} \mathrm{q}^{17}{ }^{18}$ and lipoprotein ${ }^{19}$ cannot be excluded. It is noted that specific DNA antibodies have been found in the cryoglobulins of non-SLE patients in another study in which they were considered to be a ubiquitous constituent of circulating immune complexes in many disorders. ${ }^{2021}$ In view of the frequent occurrence of antibodies to extractable nuclear antigens (ENA) in SLE sera ${ }^{22}$ and their correlation with extra-articular manifestations of $\mathrm{RA}^{9}$ we also performed a preliminary examination of cryoglobulins for the presence of these antibodies. However, ENA antibodies were not detected in the cryoglobulins of our patients with SLE, RA, or cryoglobulinaemic purpura. This is in keeping with the low incidence of ENA antibodies in cryoglobulins from SLE sera. ${ }^{14}$

One half of the SLE cryoglobulins tested bound significant amounts of $\mathrm{C} 1 \mathrm{q}$, as did all the cryoglobulins isolated from patients with cryoglobulinaemic purpura. This finding, together with the fall of ClqBA in the supernatant sera, is consistent with the concept of enrichment of immune complexes in cryoglobulins. Furthermore, the presence of ClqBA, C3, and $\mathrm{C} 4$ in cryoglobulins suggests that these immune complexes bind and activate complement. In contrast to the findings in patients with SLE and cryoglobulinaemic purpura the C1qBA of RA sera was retained in the supernatant after cold incubation and was detected in only two cryoglobulins. In some RA sera there was an increase in C1qBA on cold incubation, probably resulting from the formation of $\mathrm{Clq}$ binding immune complexes which remained soluble in the cold. The following considerations make the lack of C1qBA by RA cryoglobulins surprising: (1) The correlation of cryoglobulinaemia with extra-articular features in which complement is thought to be implicated. ${ }^{2} 3$ (2) Direct evidence of hypercatabolism of C3 in RA patients with extra-articular disease..$^{23}$ (3) The C1qBA of rheumatoid factor which was demonstrated in the cryoglobulins. (4) The presence of C3 and $\mathrm{C} 4$ in RA cryoglobulins, ${ }^{25}$ which we have quantitated and shown to be present in similar amounts as found in SLE cryoglobulins.

We have considered a number of reasons for our inability to demonstrate C1qBA in RA cryoglobulins. Technical factors may play a part-for example, the concentration of immune complexes in RA cryoglobulins may be too low. The importance of cryoglobulin protein concentration was suggested by the high $\mathrm{ClqBA}$ of cryoglobulins from patients with cryoglobulinaemic purpura. However, this does not fully explain the differences between RA and SLE cryoglobulins because six RA cryoglobulins with protein concentrations greater than $50 \mu \mathrm{g} / \mathrm{ml}$ did not bind C1q and SLE cryglobulins with similar protein concentrations did. Another factor which might explain the differences of C1qBA between RA and SLE cryoglobulins is differences in their temperature requirements; the optimum binding of complement by cryoglobulins is temperature dependent. ${ }^{26}$ A third alternative is that there are at least two distinct populations of immune complexes, of which the complement fixing variety remains soluble in the cold in RA sera but forms cryoglobulins in SLE sera. Nevertheless there is strong evidence that cryoglobulinaemia in RA is a marker of pathogenic immune complexes. $^{2} 3$

The differences in the antibody composition and complement binding properties of immune complexes in RA and SLE that we have documented may explain differences in the patterns of tissue localisation and tissue pathology observed in patients. Factors affecting localisation of immune complexes include their size ${ }^{27}$ the nature of the antigen, ${ }^{28}$ the prior deposition of antigen, ${ }^{29}$ and possibly cross-reaction of the antibody component. ${ }^{30}$ The importance of these and other variables in the pathogenesis of RA and SLE remains to be determined.

We thank the Arthritis and Rheumatism Council for their financial support, Amersham International for the gift of DNA binding kits, Dr J. T. Scott for allowing us to study some of his patients, Dr P. J. W. Venables for measuring antibodies to extractable nuclear antigens, and Mrs Barbara Ridley for her excellent secretarial assistance.

\section{References}

1 Lambert P H, Dixon F J, Zubler R H, et al. A WHO collaborative study for the evaluation of eighteen methods for detecting immune complexes. J Clin Lab Immunol 1978; 1: $1-15$. 
2 Weisman M and Zvaifler N. Cryoglobulinaemia in rheumatoid arthritis. Significance in serum of patients with rheumatoid vasculitis. J Clin Invest 1975; 56: 725-39.

3 Erhardt C C, Mumford P, Maini R N. The association of cryoglobulinaemia with nodules, vasculitis and fibrosing alveolitis in rheumatoid arthritis and their relationship to serum Clq binding activity and rheumatoid factor. Clin Exp Immunol 1979; 38: 405-13.

4 Zvaifler N J, Bluestein H G. Lymphocytotoxic antibody activity in cryoprecipitates from serum of patients with systemic lupus erythematosus. Arthritis Rheum 1976; 19: 844-50.

5 Robinson M F, Roberts J L, Verrier-Jones J, Lewis E J. Circulating immune complex assays in patients with lupus and membraneous glomerulonephritis. Clin Immunol Immunopathol 1979; 14: 348-60.

6 Weigle W O. Fate and biological action of antigen-antibody complexes. Adv Immunol 1961; 1: 283-317.

7 Theofilopoulos A, Dixon F J. The biology and detection of immune complexes. Adv Immunol 1979; 28: 89-220.

8 Holian J, Griffiths I D, Glass D N, Maini R N, Scott J T. Human anti-DNA antibody: reference standards for diagnosis and management of systemic lupus erythematosus. Ann Rheum Dis 1975; 34: 438-43.

9 Venables P J W, Erhardt C C, Maini R N. Antibodies to extractable nuclear antigens in rheumatoid arthirits: relationship to vasculitis and circulating immune complexes. Clin Exp Immunol 1980; 39: 146-53.

10 Žubler R H, Nydegger U, Perrin L H, et al. Circulating and intra-articular immune complexes in patients with rheumatoid arthritis. J Clin Invest 1976; 57: 1308-19.

11 Weeke B. Rocket immunoelectrophoresis. Scand J Immunol 1973; 2 (suppl 1/1973): 37-46.

12 Committee of the American Rheumatism Association. Diagnostic criteria for rheumatoid arthritis. 1958 revision. Ann Rheum Dis 1959; 18: 49-53.

13 Cohen A S, Reynolds W E, Franklin E C, et al. Preliminary criteria for the classification of systemic lupus erythematosus. Bull Rheum Dis 1971; 21: 643-8.

14 Winfield J B, Koffler D, Kunkel H G. Specific concentration of polynocleotide immune complexes in the cryoprecipitates of patients with systemic lupus erythematosus. J Clin Invest 1975; 56: $563-70$.

15 Stastny $\mathrm{P}$, Ziff $\mathrm{M}$. Cold insoluble complexes and complement levels in systemic lupus erythematosus. $N$ Engl J Med 1969; 280: 1376-81.

16 Davis J S, Godfrey S M, Winfield J B. Direct evidence for circulating DNA anti-DNA complexes in systemic lupus erythematosus. Arthritis Rheum 1978; 21: 17-22.
17 Agnello V, Winchester R J, Kunkel H G. Precipitin reactions of the Clq component of complement with aggregated $\gamma$-globulin and immune complexes in gel diffusion. Immunology 1970; 19: 909-19.

18 Aarden L A, Lakmaker F, Feltkamp T E W. Immunology of DNA 1. The influence of reaction conditions of the Farr assay as used for the detection of anti-ds DNA. J Immunol Methods 1976; 10: 27-37.

19 Smeenk R, Aarden L. The use of polyethylene glycol precipitation to detect low-avidity anti-DNA antibodies in systemic lupus erythematosus. J Immunol Methods 1980; 39: 165-80.

20 Roberts J L, Lewis E J. Identification of antinative DNA antibodies in cryoglobulinaemic states. Am J Med 1978; 65: 437-45.

21 Roberts J L, Lewis E J. Immunochemical demonstration of cryoprecipitable anti-native DNA antibody and DNA in the serum of patients with glomerulonephritis. J Immunol 1980; 124: $127-33$.

22 Kurata N, Tan E M. Identification of antibodies to nuclear acidic antigens by counterimmunoelectrophoresis. Arthritis Rheum 1976; 19: 574-80.

23 Nydegger U E. Zubler R H, Gabay R, et al. Circulating complement breakdown products in patients with rheumatoid arthritis. Correlation between plasma $\mathrm{C} 3 \mathrm{~d}$, circulating immune complexes and clinical activity. J Clin Invest 1977; 59: 862-8.

24 Bourke B E, Moss I K. Maini R N. Measurement of the complement $\mathrm{C} 3$ breakdown product $\mathrm{C} 3 \mathrm{~d}$ by rocket immunoelectrophoresis. J Immunol Methods 1982; 48: 97-108.

25 Wilson M R, Arroyave C M. Miles L. Tan E M. Immune reactants in cryoproteins. Relationship to complement activation. Ann Rheum Dis 1977; 36: 540-8.

26 Rother U, Rother K, Flad H D, Miescher P A. Bithermic complement activation in cryoglobulinaemic serum. Eur J Clin Invest 1972; 2: 59-65.

27 Levinsky R J, Cameron J S. Soothill J F. Serum immune complexes and disease activity in lupus nephritis. Lancet 1977: i: $564-7$.

28 Finbloom D S, Magilvay D B, Harford J B. Rifai A, Plotz, P H Influence of antigen on immune complex behaviour in mice. $J$ Clin Invest 1981; 68: 214-24.

29 Izui S, Lambert $\mathrm{P}$ H, Miescher $\mathrm{P}$ A. In vitro demonstration of a particular affinity of glomerular basement membrane and collagen for DNA. A possible basis for local formation of DNA-anti-DNA complexes in systemic lupus erythematosus. $J$ Exp Med 1976; 144: 428-43.

30 Schoenfeld Y, Rauch J, Massicotte H, et al. Polyspecificity of monoclonal lupus autoantibodies produced by human-human hybridomas. $N$ Engl J Med 1983; 308: 414-20. 